\title{
Attitudes towards Teachers' Motivation, and Classroom Strategy, in English Language classrooms
}

\author{
Samira Pahlavanpoorfard \\ Department of Language and Literature, Islamic Azad University, Larestan Branch \\ E-mail: samira_pahlavanpoorfard@yahoo.com \\ Afshin Soori \\ Department of Language and Literature, Islamic Azad University, Larestan Branch \\ E-mail: afshin_soori@yahoo.com
}

\author{
Doi:10.7575/aiac.alls.v.5n.1p.164 \\ URL: http://dx.doi.org/10.7575/aiac.alls.v.5n.1p.164
}

Received: 03/01/2014

Accepted: 27/02/2014

\begin{abstract}
This study aimed at investigating the attitudes of Iranian EFL students towards teachers' motivation and classroom strategy in English classroom. The subjects of the study included a sample of 235 students in their classes. The findings of this study revealed that teachers' motivation and classroom strategy used by teachers have effects on the students' motivation.
\end{abstract}

Keywords: student motivation, teacher motivation, strategy used by teachers

\section{Introduction}

In the world of education, motivation is a factor that can play a significant role in the success of second or foreign language learning in a language classroom. To Dornneyei (1998) "motivation provides the primary impetus to initiate learning the second language and later the driving force to sustain the long and often tedious learning process" (p.117). Motivation, however, is "a complex" and "multifaceted construct" (Gardner, 1985; Williams \& Burdoen, 1997). In many instances, students may face many different obstacles in learning English because they are demotivated to learn. Learning situation contains many factors like classroom environment, teacher, learning context, teaching methods, classmates, and teacher personality (Dörnyei, 1994). However, the role of teacher motivation on the students' achievement shouldn't be ignored.

During the last few years research about motivation has focused on different factors which are responsible for learning a second or foreign language. Researchers refer to the role of teachers and their motivations and behaviors as a determinant factor for achievement a second language (Kikuchi, 2009; Sakai \& Kikuchi, 2009; Tanak, 2005). Some other studies point to the role of teachers in the learners' motivation. These studies express the influential roles of teachers for helping the students in the process of second language acquisition. In fact, teachers can play as facilitator, initiator, motivator, consultant, and supporter in a language classroom (Al Kaboody, 2013). These roles can be considered as influential factors in achievement of a second language.

According to Ramage (1990) teachers should be motivated themselves and they should try to increase the learners' motivation in order to actively engage in the learning of a target language. However, the effect of teacher and his teaching strategies on motivating the students depend on perceptions of those strategies by the students. In this case, many empirical studies refer to the teacher's motivation on the learners' level of achievement of a second language (Dörnyei (2001).

According to Dornyei (1994 as cited in Al Kaboody, 2013) "teacher-associated components that influence learners are language learners' affiliation (i.e., learners' desire to please teachers), teacher's style of teaching, and the use of particular teaching strategies, including modeling task-presentation and feedback" (p.49). The interaction between L2 learners and the teachers include many different factors include learning experiences, and feedback rewards which are relevant factors that influence on the learners' motivation for learning (Williams \& Burden, 1997). Oxford and Shearin (1994) refer to five implications for the role of the teacher in understanding motivation. Oxford and Shearin (1994 as cited in Al Kaboody, 2013) propose that the teachers should "(a) figure out learners' real reasons for learning the L2; (b) help students build challenging but achievable goals; (c) show students the benefits of learning the L2; (d) create a safe, welcoming, and non-intimidating teaching environment; and (e) motivate students to develop high but realistic intrinsic motivation" (p.49).

To be more influential and assisting the learners to attain a high level of achievement in second language learning, a teacher should be familiar with learners' goals and needs. Brophey (1998) argues that teachers should teach what is related to the learners' needs. However, if it is not related to their needs their motivation to learn will be decreased 
dramatically when the learners learn something they do not see any relevant to their needs. In this case, Dörnyei (2001) proposes that the materials made by teachers should be relevant as much as possible to the students' lives and teachers should try their best to supply some more activities in textbooks with more relevant materials in order to motivate the learners to learn. Finally, "teachers should help students create realistic beliefs about language learning. Some learners bring some unrealistic learning beliefs about how much progress or learning they can achieve in a particular class. If they do not see that their beliefs or expectations are not achieved, they will become disappointed and lose interest in the course (Al Kaboody, 2013, p.50). Teachers should also inform the students of the complexity of the learning process. Moreover, they should make the students familiar with different ways of achieving success in learning a second language and also encourage the learners to find distinct ways of learning. It seems that if a teacher makes the learning experience enjoyable and stimulation, he can maintain the motivation among the students in the language classroom. This can occur in many different ways. For example, by varying their teaching styles, presentations, learning tasks, teachers are able to make teaching more interesting. Interesting tasks are viewed as essential components of motivation (Anderman \& Anderman, 2010). Teachers can also make the teaching interesting if they introduce novel techniques and make the task more challenging (Al Kaboody, 2013). However, the tasks presenting by teachers can be motivating or demotivating depend on how the teachers administer the tasks. Moreover, the teachers should clarify the aim of the tasks, arouse learners' anticipation toward the task, and offer some useful strategies for doing the task (Al Kaboody, 2013).

Another important issue for maintaining the motivation among the students is self-esteem. According to Dornyei \& Ushioda (2011) the learners cannot progress if they have doubt about their abilities in learning a second language. To this end, motivated teachers can increase the learners' self-confidence in different ways. For instance, teachers can focus positively on what the learners are able to do rather than on what they cannot do and giving a chance to use their capabilities to get to a high level of achievement in second language learning. In order to preserving the motivation among the students, teachers can also make the teaching context relaxing and less stressful by demonstrating the students a positive image of their strengths.

Learning autonomy is another important issue that should be fostered by teachers to help students have a better achievement in learning a second language (Dornyei\& Ushioda, 2011). When discussing maintaining motivation, most researchers emphasize the teacher's role. However, to make the learning beneficial for the students, they should be given a good opportunity to share the responsibility in the classroom. According to Al Kaboody (2013) "learners who motivate themselves exhibit more success in pursuing their goals. Teachers can promote their students' self-motivation by drawing their attention to useful strategies, such as favorable expectations, incentives, dealing with procrastination and boredom, and eliminating distractions" (p. 52).

\section{Review of related literature}

During the past decades a large number of studies (eg., Clément,1980; Gardner, 1985 and MacIntyre, Clément \& Noels, 1998) have been written on the students' motivation and its relationship with second language achievement. These studies have proposed some models and phenomena related to motivation in the classroom. These models point out the essential roles of motivation in relation with learning a second or foreign language. However, the concepts of how and why the motivation is important may be different from one model to another model (Bernaus, \& Wilson 2009). These models are responsible for identifying the characteristics of the individuals and cause the achievement differences in learning a second language in a classroom. According to Gardner (2007) second language learning is not like other subjects because it includes the elements of another culture like vocabulary, pronunciation, and language structure, while, the other subjects contain elements which are related to just one culture. Bernaus, \& Wilson (2009) state that these two "educationally relevant and culturally relevant variables should be considered when attempting to understand the process by which a second language is learned" (p. 26).

There are many studies to suggest how motivation will be able to be developed and supported. Among numerous studies, Dörnyei and Csizér (1998) refer to ten teachers' commandments for improving the students' motivation. Williams and Brurden (1997) also explained that teachers can use different ways to motivate the students.

The review of some studies (e.g. Gardner, Masgoret, Tennant, \& Mihic 2004) revealed that what are taking place in a language classroom can affect on the students' perspectives and motivation. Gardner et al., (2004) believed that the students' level of motivational intensity, their attitudes towards learning a foreign language, integrative orientation, course evaluation, class anxiety will be diminished significantly over a course of year. Similar findings were shown in a study by Gardner and Bernaus (2004) on high school students learning English as a foreign language. That study also indicated that scores on integrativeness and motivation decreased significantly from the beginning of the year to the end. To this end, it seemed that there was a "significant interaction between the level of achievement attained in the class and changes over time in attitude toward the learning situation" (Bernaus, \& Wilson, 2009, p.27).

Reviewing the related literature shows some studies on teachers' motivation (e.g. Tragant, 1996; Kassabgy, Boraie, and Schmidt, 2001), strategies used by teachers in language classrooms (Donitsa-Schmidt, Inbar and Shohamy, 2004; Madrid, 2002), and students' motivation Schmidt and Watanabe, 2001).

There are some other studies which investigated on the role of teachers' and students' perceptions. Among the researchers, Jacques (2001) examined both teachers' and students' motivation also their preferences for receiving instruction in the language classroom. He referred to the relationship between some motivational characteristics and perceptions of strategy use. In a study Guillautaux and Dörnyei (2008) investigated the link between the motivation of 
teachers for teaching and learners' motivation in a language classroom. The results of their study revealed that there was a direct relationship between the teachers' motivation and language motivation in the language classroom. As it was mentioned earlier, Bernaus and Gardner (2008 as cited in Bernaus, \& Wilson, 2009) stated that language achievement is not related to motivational strategy use reported by the teachers but it is when reported by the students.

The current study investigates language achievement among the Iranian EFL students regarding the teacher's motivation and the motivating strategies they use in the classroom. Regarding this issue, the research question is: What are the attitudes of the students' toward the teachers' motivation and classroom strategy they use in the classroom?

\section{Method}

The participants of the current study included 235 students. They were EFL students from 3 public and 3 private high schools in Larestan, Iran. All these students were in the last year of secondary education. They were all in the range of 16 to 17 years old.

In order to identify the classroom strategies by teachers, the researcher of this study administered a questionnaire to Iranian EFL students. It contained two parts. In the first part, the researcher asked the students to rate to what extent the teachers were successful to use 26 strategies (mentioned earlier) in the classroom. The questionnaire was a Likert Type questionnaire with seven options. The students' scores obtained from Innovative and Traditional strategies. In the second part of the questionnaire, the researcher administered a mini-AMTB that had been modified by the Gardner, MacIntyre (1993) and Bernaus, Gardner (2008). "Six variables were derived from scores on this test because some scales were aggregated" (Bernaus, \& Wilson, 2009, p. 30). These variables included:

Integrativeness. To Bernaus, \& Wilson (2009) integrativeness is a concept that refers to general-relevant attitudes which is related to learning another language. This concept reveals a dimension of openness to other cultural communities that focuses on the ability to accept material from another cultural community (Bernaus, \& Wilson 2009).

Attitudes toward the Learning Situation. This concept is related to attitudes of the students towards the learning situation. Here, the AMTB focuses on just two aspects as Evaluation of the English Teacher and Evaluation of the English Course (Bernaus, \& Wilson 2009).

Mottivation. This concept indicates to what extent the students are motivated to learn second language. The AMTB measures, Motivational Intensity, Desire to Learn English, and Attitude toward Learning English which are relevant to the classroom context, effort, desire, and the students' attitudes towards learning second language (Bernaus, \& Wilson 2009).

Language Anxiety. According to Bernaus \& Wilson (2009) this concept is related to the concerns and discomfort of the students when they are using a second language. In AMTB, this concept is measured based on English class anxiety, and English use anxiety.

Two other variables were also measured. They were Instrumental Orientation, and Parental Encouragement.

\section{Results and Discussion}

To analyze the data mean scores of the students in each class were calculated. The scores for the students were obtained in terms of the measures administered to them. To this end, this study was supposed to explore the how students view using the teaching strategies, and also the degree of motivation among the teachers in the classroom.

Factor analysis was used to identify the correlation among L2 variables. Three factors were calculated based on eigenvalues were greater than 1.0 , which were account for $73 \%$ of the variance. The eigenvalue of the fourth factor was .94. The result of Scree plot revealed that the fourth factor ought to be included. Therefore, the residual correlations confirmed it. About $81 \%$ of the residuals were less than .10 with these four factors. So, four factors accounted for $78 \%$ of the whole variance.

Factor I was taken from the measure of students' English achievement and four of variable related to AMTB. It showed that the high the levels of achievement were obtained with high levels of Instructional Orientation, parental encouragement and motivation for learning English. Integrative motivation proposes that achievement for learning English may be higher in classes where the students are integratively motivated. In fact, this is one of the measures that help Parental Encouragement. It reveals that "classes that differ in integrative motivation might well receive differential support from parents of the students involved" (Bernaus, \& Wilson 2009, p.31).

Factor II was determined by five measures. The responses to items by the students indicated that students had positive attitudes towards the learning situation and they had high motivation toward Traditional and Innovative strategies used frequently in the classroom. They also preferred teachers with high levels of motivation. An important issue about this factor relates to the association of the characteristics of the class with teacher motivation which is identified by this factor. It seems that there are relationships between the ways motivated teachers teach English, the degree their students perceive them as strategies using in the classroom and the students' motivation to learn English. According educational experts, teacher's motivation plays an essential role in the teaching or learning a second language.

Factor III was determined by two other measures. The students were satisfied with Traditional Strategies that were used by the teachers. It seems that both teachers and students agree about the use of Traditional Strategies, but there was no agreement between them about the use of Innovative strategies. The probable reason was that these types of strategies were directed toward teaching the language. However, innovative strategies were directed to the students rather than 
learning. To Bernaus, \& Wilson (2009) Traditional Strategies is related to students with lower levels of English achievement.

Factor IV was determined by two variables. In the classes where the teachers used Innovative Strategies, the students had lower levels of Language Anxiety than the classes the teachers used the Traditional Strategies. To this end, the teachers should use Innovative strategies to reduce anxiety among the students. Consequently, this factor is considered as Teacher Innovative Strategy Use. According to Horwitz \& Cope (1986) language anxiety is negatively associated with language anxiety and the "extended use of innovative strategies is associated

with decreased language anxiety" (Bernaus, \& Wilson 2009, p.31).

The outcome of this study attested to the importance of Bernaus, \& Wilson 2009 with a sample of 694 secondary students. The finding of this study proposes that students should be motivated in the language classrooms. In fact, when the students are highly motivated, the students try their bests to take part in class activities and feel more motivated.

\section{References}

Bernaus, M., Wilson, A., and Gardner, R.C. (2009). Teachers' motivation, classroom strategy use, students' motivation and second language achievement. JPOOSRÉT AM LAINNUGEULA VRUEMZ,12. pp. 25-36.

Clément, R. (1980). "Ethnicity, contact and communicative competence in a second language".

In H. Giles, W. P. Robinson \& P. M. Smith (Eds.) Language: Social psychological perspectives: Selected papers from the First International Conference on Social Psychology and Language held at the University of Bristol, England, July 1979. Oxford: Pergamon.

Donitsa-Schmidt, S., Inbar, O. and Shohamy, E. (2004). The Effects of Teaching Spoken Arabic on Students' Attitudes and Motivation in Israel. The Modern Language Journal, 88: 217- 228.

Dörnyei, Z. (1994). Motivation and motivating in the foreign language Classroom. Modern Language Journal, 78: 273284. Dörnyei, Z. (1998). Demotivation in foreign language learning. Paper presented at the TESOL 98 Congress, Seattle, WA

Dörnyei, Z. (2001). Motivational strategies in the language classroom. Cambridge, Cambridge University Press.

Dörnyei, Z. \& Csizér, K. (1998). "Ten commandments for motivating language learners: Results of an empirical study". Language Teaching Research, 2: 203-229.

Dörnyei, Z., \& Ushioda, E. (2011). Teaching and researching motivation (2nd ed.). Harlow, England: Pearson Longman

Gardner, R. C. (1985). Social psychology and second language learning: The role of attitudes and motivation. London: Edward Arnold Publishers.

Gardner, R. C. (2007). "Motivation and second language acquisition". Porta Linguarum, 8: 9-20.

Gardner, R. C. \& Bernaus, M. (2004). "The applicability of the Attitude/Motivation Test Battery to EFL students in Spain". Unpublished manuscript, University of Western Ontario, London, Canada.

Gardner, R. C., Masgoret, A.-M., Tennant, J., \& Mihic, L. (2004). "Integrative motivation:

Changes during a year-long intermediate-level language course". Language Learning , 54: 1-34.

Guillauteaux, M. J. \& Dörnyei, Z. (2008). "Motivating Language Learners: A Classroom Oriented Investigation of the Effects of Motivational Strategies on Student Motivation". Tesol Quarterly, 42, (1): 55-77.

Horwitz, E. K.; Horwitz, M. B.; Cope, J. (1986). "Foreign Language Classroom Anxiety”. The Modern Language Journal, 70: 125-132.

Jacques, S. R. (2001). "Preferences for instructional activities and motivation: A comparison of student and teacher perspectives". In Z. Dörnyei \& R. Schmidt (Eds.), Motivation and second language acquisition. Honolulu: University of Hawaii Second Language Teaching and Curriculum Center.

Kassabgy, O., Boraie, D., \& Schmidt, R. (2001). "Values, rewards, and job satisfaction in ESL/ EFL”. In Z. Dörnyei \& R. Schmidt (eds.), Motivation and second language acquisition. Honolulu: University of Hawaii Second Language Teaching and Curriculum Center.

Kikuchi, K. (2009). Listening to out learners' voices: What demotivates Japanese high school students? Language Teaching Research, 13, 453-471.

MacIntyre, P. D., Clément, R. \& Noels, K. (1998). "Conceptualizing willingness to communicate in a L2: A situational model of L2 confidence and affiliation". The Modern Language Journal, 82: 545-562.

Madrid, D. (2002). "The Power of the FL Teacher's Motivational Strategies". Cauce, 25.

Oxford, R., \& Shearin, J. (1994). Language learning motivation: Expanding the theoretical framework. The Modern Language Journal, 1 (78): 12-28.

Ramage, K. (1990). Motivational factors and persistence in foreign language study. Language Learning, 40, 189-219.

Sakai, H., \& Kikuchi, K. (2009). An analysis of demotivators in the EFL classroom. System, 37, 57-69. 
Schmidt, R. \& Watanabe, Y. (2001). "Motivation, strategy use and pedagogical preferences in foreign language learning". In Z. Dörnyei \& R. Schmidt (eds.), Motivation and second language acquisition. Honolulu: University of Hawaii Second Language Teaching and Curriculum Center.

Tanaka, T. (2005). Teacher influence on learner motivation. Osaka Female Junior College, Retrieved in the EFL classroom. System, 37, 57-69. Retrieved from http://www.wilmina.ac.jp/ojc/kiyo_2005/kiyo_35_PDF/2005_06.pdf.

Tragant, E. (1996). “The impact of teachers' beliefs on their practice in activity structuring”. Atlantis XVIII: 407-415.

Williams, M. \& Burden, R. (1997). Psychology for Language Teachers. Cambridge, UK: Cambridge University Press. 